УДК: 81:929 Белић А. DOI: https://doi.org/10.18485/belic_slv.2017.2.ch5

Неђо Јошић

\title{
АЛЕКСАНДАР БЕЛИЋ У УСПОМЕНАМА СТРАНИХ СЛАВИСТА
}

О стогодишњици рођења Александра Белића Српска академија наука и уметности објавила је Зборник радова о Александру Белићу (Београд 1976). У низу јубиларних издања (Зборника филолошких и лингвистичких студија А. Белићу поводом 25-годиштице юегова научног рада из 1921. и Зборника лингвистичких и филолошких расправа А. Белићу о четрдесетогодиштици юегова научног рада из 1937), ово је први прави зборник посвећен животу, научноистраживачком, педагошком и организационом раду академика Александра Белића. Наведени зборник међу бројним рефератима махом наших научника садржи и осврте појединих угледних слависта обликоване као својеврсне успомене на Александра Белића. Овај реферат нема за циљ да вјерно интерпретира њихова сјећања, већ да у некој мјери дочара њихов дух, призове и унеколико освијетли климу у којој су настајали неки Белићеви славистички радови, његову улогу уопште у славистичким гибањима прве половине XX вијека. Белићево лингвистичко дјело „огромно и по обиму и по теоријском доприносу науци" (Јовић 1972: 57), овдје се узима само као оквир у којем се поједини његови сегменти освјетљавају из угла других слависта, дјелатника на истом славистичком научном пољу, Белићевих пријатеља или ученика. Та сјећања чине и одређено свједочанство о Белићевој лингвистици као жижи „у којој су се преламале модерна европска и модерна наша наука о језику" (Станојчић 2016: 20).

\section{André Vaillant: Quelques souvenirs sur Alexandre Belić}

Међу неколицином слависта у Зборнику радова о Александру Белићу (Београд 1976) своје успомене на Александра Белића изнио је и чувени француски слависта Андре Вајан. У крајње сажетом сјећању насловљеном као Quelques souvenirs sur Alexandre Belić (Вајан 1976), свој однос према Александру Белићу и његовом научном дјелу он је изразио у уводном 
дијелу назначенога текста. „Dans un article de la Revue des Études slaves, XXXVII, 1960, p. 7-16, j’ai dit tout ce que je pensais sur l'oeuvre scientifique d'Alexandre Belić, mon admiration pour elle, et son importance pour l'histoire des études slaves qui lui assigne le rang des tout premiers linguistes, de Saussure, Leskien, Meillet. Je n'ai plus à donner que quelques souvenirs détudiant sur le maître et sur l'homme" (Вајан 1976: 53).

У Вајановим успоменама из прве фазе његових славистичких интересовања оличена је сва строгост Белићеве научне методологије, његов научноистраживачки дух, савјетодавни и менторски однос.

Већ довољно формиран на строгој научној методологији својих учитеља Антоана Мејеа и Пјера Боатјеа, Вајан се присјећа како је био изненађен Белићевом јасноћом у изразу и методолошком строгошћу у приступу језичким фактима. Белић је заправо обиљежио сам почетак Вајанових славистичких интересовања: „En abordant son cours, j’ai eu la surprise, avec ma connaissance rudimentaire du serbe, de le comprendre tout de suite, tandis qu'il ma fallu une bonne quinzaine de jours pour commencer à suivre Pavle Popović dans son débit plus rapide. Ce qui ne tenait pas à la différence entre linguistique et histoire littéraire, mais à une différence de tour d'esprit. L'esprit de Belić était logique, et dominé par la logique et le besoin de clarté" (Вајан 1976: 53). Јасноћу Белићевих факата и јасноћу Белићевог излагања Вајан је доживљавао као откриће. Па ипак, иза Белићева израза (очигледно је да ...) често коришћеног у предавањима, није било увијек све тако очигледно, све тако једноставно - иза тога је морало да слиједи ново и снажно удубљивање да би се до оног што је Белић предочавао као очигледно, заиста и дошло. У том погледу Вајан наводи гласовну алтернацију $\mathrm{cm}: u m \rightarrow c m:$ ић (код српских глагола типа пустити : пуштен), закључујући како су „фонетски закони вредни поштовања”, али да се и они мијењају: „La révélation était due à la clarté des faits serbes, et à la clarté de leur exposé par Belić" (Вајан 1976: 53). А о новим открићима Вајан је навео и сљедеће: "Je dois à Belić la découverte de la dialectologie sur le terrain, même si je n'ai pas pu la pratiquer, la dialectologie vivante, moi qui m’étais passionné à Paris pour les dialectes grecs dans le cours de Bourguet à l' École des Hautes Études. Je lui dois une solution, sortie de la métatonie et de la théorie vague du neo-akut - et il ma fallu cinq à six lectures successives de ses Akcenatske studije pour arriver à voir un peu clair dans la rigueur logique de sa démonstration" (Вајан 1976: 54).

У другом дијелу својих успомена Вајан даје скицу о Белићу као учитељу, његовој ефикасности и ауторитету у вођењу студената. Ту помиње своју докторску дисертацију Језик Доминка Златарића. Знајући за значај Доминка Златарића у дубровачкој књижевности, тему доктората му је 
предложио Александар Белић. О изради наведене тезе, Вајан је посве кратко навео: „il m’a contrôlé et conseillé sur le premier essai par où je l'abordais, la prose de Zlatarić, et il ma fait toute confiance ensuite pour lélaboration du travail"(Вајан 1976: 53). Тако успјешну сарадњу овај француски слависта није имао у изради дијалектолошке студије о једном македонском говору. Аутор сјећања изричито не наводи о којем је то говору ријеч, али на образложени приједлог Белић му је у писму из 1924. одговорио: „Vous connaissez bien mon opinion sur la méthode qu'il faut adopter dans létude des dialectes macédoniens. Si vous voulez travailler sous ma direction, cela signifie que vous l'adoptez" (исп. Вајан 1976: 54).

Као што се из наведених редака могло да закључи - Александар Белић је био веома ауторитативна фигура. Ауторитативност се темељила на познавању језичких факата, на јасном методолошком плану који је сугерисао у сарадњи, на схватању да општи научни интерес мора да буде надређен сваком другом. „C'est le souvenir d'un grand savant, et d'un maître dont son élève garde fidèlement la mémoire”(Bajaн 1976: 54).

\section{Роман Якобсон: Александр Белич на Пранской бонологической конференции}

Осврт или својеврсно сјећање на Александра Белића Роман Јакобсон је изложио у краћем спису насловљеном као Александр Белич на Пражской фонологической конференции (Јакобсон 1976). Прашка фонолошка конференција организована под руководством чланова Прашког лингвистичког кружока одржана је с јесени 1930. године. У оквирима рада комисије за структурни опис савремених словенских језика, разради фонологије и фонолошких принципа било је посвећено најважније мјесто. Свој прилог расправи наведеним питањима дали су међу осталим А. Белић, В. Дорошевски, В. Матезијус, Н. Трубецки, Р. Јакобсон. Трубецки и Јакобсон били су нарочито активни, „Они су душа Прашкога кружока и руководиоци његовим радом” (Белић 1931: 187). ${ }^{1}$ Прашки кружок - како саопштава Јакобсон - послије чувене Прашке конференције надаље је имао за циљ сазивање новог скупа посвећеног средишњим питањима

${ }^{1}$ Напоменимо узгред да је - како то Јакобсон тврди - својеврсни лингвистички кружок у Москви чија се активност одвијала под патронатом Ф. Фортунатова, у каснијем периоду служио као образац при стварању знаменитог Прашког лингвистичког серкла (1926), те да је као такав имао видан утицај на развој језичких схватања и у другим лингвистичким срединама (исп. Половина 2016: 57). 
фонологије, њеним принципима, теоријским и методолошким оквирима. Та питања била су укључена у програм Другог међународног лингвистичког скупа одржаног у Женеви 1931. године.

Средишње мјесто у Јакобсоновом осврту чини Белићев прашки реферат из 1930. године поднесен под насловом „Laccent de la phrase et l'accent du mot" у оквиру комисије за опис словенских језика. Годину дана касније Белићев реферат штампан је у четвртом тому зборника Travaux du Cercle Linguistique de Prague (1931, стр. 183-188). Белићева гледишта изнесена у назначеном реферату Роман Јакобсон је укратко оцијенио на сљедећи начин: „Тонкие наблюдения Белича над борьбой между фразной интонацией и индивидуальным политоническим ударением слов в различных сербохорватских говорах представляют широкий интерес не только для описательной и исторической акцентологии славянских языков, но также для общей теории соотношения между словесной и синтаксической фонологии, в частности для решения вопроса о значимости и приложимости понятия 'моры' в анализе языкового строя" (Јакобсон 1976: 56). Дочаравајући питања фонолошке проблематике и сам дух излагања на Прашкој фонолошкој конференцији, Јакобсон се присјећа живог учешћа Александра Белића, кога је очито снажно заокупљало питање фонеме, њене функције и њеног значаја, уопште питање звуковног састава ријечи. То је било вријеме када су полагани основи фонологије, вријеме које је према Белићевим схватањима захтијевало даљу разраду фонолошких питања, уобличавање поузданијих гледишта о фонеми „и ее отношение к тому звуковому материалу, которым оперирует фонетика" (Јакобсон 1976: 56). ${ }^{2}$

Белићева запажања и ставове изложене на Прашкој фонолошкој конференцији Јакобсон даље расвјетљава позивајући се на поглавље посвећено форми и значењу ријечи у Белићевом синтетичком дјелу $O$ језичкој природи и језичком развитку (1941). Тамо изложена гледишта о фонологији и њеном односу према фонетици Јакобсон тијесно повезује са схватањима Фортунатовљеве школе. Та схватања, сматра Јакобсон, неупоредиво су се дјелотворније одразила на развој Белићевих фоно-

2 У вези с тим, општу оцјену лингвистичких гледишта за која се залагао Прашки лингвистички кружок, Александар Белић је изнио веома брзо послије завршетка Прашке фонолошке конференције: „И сада се може рећи за овај покрет као и за све друге који су му претходили или који ће за њим доћи: у дефиницијама језичким може бити и сме бити само оно што истиче из језичких појава, из језика. Докле и овај покрет буде на томе терену, он ће остајати лингвистичка дисциплина; иначе ће отићи у област науке која са њом непосредне везе нема" (Белић 1931: 189). 
лошких гледишта него психофонетичко учење које је заступао Пољак Бодуен де Куртене.

Прашку фонолошку конференцију и поједине њене учеснике здушно је пратио лист Prager Presse. Роман Јакобсон у прилогу Александр Белич на Пражской фонологической конференции даје нешто ближих обавјештења о улози тог угледног листа: помиње бесједу Александра Белића насловљену као „Пути к обновлению языкознания”, интервју с Белићем, извјештај о преводу Сосировог дјела Курс опште тингвистике (1907) на њемачки језик итд. (исп. Јакобсон 1976: 56-57). Све су то чиниоци који доприносе успостављању оштрије слике о граду Прагу, културној и научној клими у њему. Чувена Прашка конференција из 1930. године у научном свијету остаће да се памти као кључни скуп за развој лингвистичке, посебно фонолошке мисли. Угледни слависти (Трубецки, Јакобсон, Белић, Матезијус и др.) обиљежили су њен рад, те се данас с правом сматра да Прашка фонолошка конференција уистину носи њихова мисаона обиљежја.

Самуил Борисович Бернштейн: Памяти академика Александра Белича

У уводном дијелу свога прилога Памяти академика Александра Белича, Самуил Борисович Бернштейн (Бернштајн 1976) угрубо је оцртао стање славистичке науке у првим деценијама XX вијека: у том периоду било је доста слависта који су оставили значајнији траг у испитивању својих националних језика, али се тај број знатно смањује када су посриједи научници што су истовремено разрађивали фундаменталне проблеме прасловенског језика и упоредне граматике словенских језика; посве мали број њих устрајно се занимао за општетеоријска језичка питања. „В этом небольшом списке ученых имя академика А. Белича будет стоять на одном из первых мест" (Бернштајн 1976: 61).

Бернштајнов прилог пружа обиље података о Белићевим московским годинама, о славистичким скуповима, Белићевим везама с Руском академијом наука и сарадњи с њом, о појединим личностима из свијета славистике с којима је водио преписку итд. Објављивање преписке свог вишегодишњег предсједника Бернштајн ставља као обавезу Српске академије наука и уметности (Бернштајн 1976: 64). Ово су све фактори битни за уобличавање Белићевог животописа, за одређивање његове улоге у проучавању српског (српскохрватског) језика и словенске филологије. Па ипак, срећније је да се засад вратимо на Белићево научно сазријевање 
и његову улогу у развоју славистике - онако како је то видио аутор у прилогу Памяти академика Александра Белича.

Белићев фактички успон у свијету словенске филологије отпочео је (што Бернштајн у прилогу испушта) одбраном докторске дисертације $O$ историјском развитку словенских деминутивних и амплификативних субикса у словенским језицима штампаном 1901. у Јагићевом Архиву за словенску филологију. Представљајући Белића као плодотворног научника у скоро свим областима словенске филологије, Бернштајн се непосредније осврће на Белићев спис Мысли о собирании диалектологического материала (изложене у писму упућеном Бодуену де Куртенеу 1913. године). ${ }^{3}$ Белића означава као дијалектолога велике даровитости, истраживача који одлично фиксира „все тонкости народной речи”. У том духу Бернштајн оцјењује и Белићеве Мысли: „С тех пор прошло много лет, многое изменилось в науке о славянских диалектах, в методике сбора диалектного материала, в его обработке, но ,Мысли' Белича до сих пор входят в список обязательной литературы всех начинающих диалектологов" (Бернштајн 1976: 61). Дијалекатска језичка грађа за Белића је представљала основни извор изучавања матерњег језика; древни споменици српске писмености за њега су у том погледу имали периферни значај. Осмишљеним дијалектолошким приступом, прије свега комбиновањем дијалекатских факата, он је налазио пут за разрешење питања еволуције српског гласовног система „и форм сербской речи”. У том погледу - наводи Бернштајн - као образац може да служи Белићева Диалектологическая карта сербского языка (1905). ${ }^{4}$ На молбу Алексеја Шахматова који

3 Белићеве Мисли појавиле су се 1913. године у руском преводу под насловом Письмо проф. А. И. Белића кь И. А. Бодуэну-де-Куртенэ о сабираніи діалектологическаго матеріала. Овај Белићев прилог штампан је касније у Јужнословенском филологу у српској верзији под називом Мисли о прикупљаюу диалекатског материала (Белић 1926-1927: 1-10). Српској верзији претходио је чешки превод. У кратком предговору чешкога превода Бодуен де Куртене је међу осталим истакао његов значај: „И поред овог карактера (тј. облика приватног писма), расправа проф. Белића има у себи драгоцена и незаменљива упутства и треба да послужи као вођа (vademecum) сваком диалектологу који цени време и који не тежи неостварљивим циљевима (тј. богаћењу не само диалектологије, него и фолклора, усмене књижевности итд.). Зато ја сматрам да је веома потребно да се то писмо наштампа и да се са његовим садржајем упознају и сви други стручњаци, а не само ја" (исп. Белић 1926-1927: 1-2).

4 Напоменимо узгред да је некако упоредо с овим изашла и чувена Белићева дијалектолошка студија Дијалекти источне и јужне Србије (Београд 1905), дјело „каквим се - подвукао је М. Стевановић - у овој дисциплини још није могла похвалити наука ниједног словенског народа” (Стевановић 1976: 9). 
је у изучавању језичке еволуције такође на прво мјесто стављао народне говоре а не древне споменике писмености, Белић је релативно брзо завршио поменути рад и поред недовољности дијалекатске грађе и других потешкоћа које стоје на путу цјеловитом прегледу, ${ }^{5}$ „Специалист легко определит, что автор „Диалектологической карты сербского языка” - наводи Бернштајн - принадлежит к московской лингвистической школе акад. Ф. Ф. Фортунатова. И это так! Методические принципы автора, его отношение к диалектному материалу, наконец, анализ самого материала - все это выполнено так, как учил своих молодых учеников основатель московской лингвистической школы" (Бернштајн 1976: 62). Московска лингвистичка школа имала је кључну улогу у Белићевом научном формирању па и у утврђивању дјелокруга његових лингвистичких интересовања. ${ }^{6}$ Прије Фортунатовљева преласка у Петроград (1902), Александар Белић је у Москви слушао последњи дио његових московксих предавања. Фортунатов је баш у то вријеме устрајно размишљао о акаценатској проблематици; Белићу као даровиту ученику веома се често обраћао „с различными вопросами из области сербской интонации, внимательно слушал его родную речь" (Бернштајн 1976: 63). У Академији наука, на иницијативу А. Шахматова, била је формирана специјална комисија за изучавање српскохрватске акцентуације. Све је то код Белића побудило живо интересовање за темељито испитивање нашег акценатског система. Његов пут од јужнословенске акценатске проблематике водио

${ }^{5}$ Оскудицу у грађи давно је поменуо и Стјепан Куљбакин износећи своју општу оцјену о овом дјелу: „Прво дело [Диалектологическая карта сербского языка], и поред све оскудице у научној грађи која је тада постојала, даје науци одличну ориентацију у питању о српским дијалектима и о њиховим узајамним односима. Писац је, наравно, употребио све податке које је имала наука у то време, али је, поред тога, унео и своју нову грађу, изнео и своје нове погледе, одредио границе појединим дијалектима, дао груписање ових дијалеката са историског гледишта, везујући уједно историју српског језика са историјом српског народа" (Куљбакин 1921: Х).

6 У свом кратком а садржајном приказу Руске лингвистичке школе пишући о језичкој мисији Ф. Ф. Фортунатова, Белић је међу осталим драгоцјеним појединостима навео и ово: „Иначе и остали, ближи и даљи ученици и поштоваоци Фортунатова [...] долазили су у Москву да поздраве патријарха лингвистике, који је имао подједнаке љубави и поштовања за све и необичне природности у опхођењу са свима. Ти састанци, то стално општење са свима, разговори о свима питањима науке и подстицаји за нове радове били су много значајнији него многи институти и семинари. На њима је научни интерес био уздигнут до једне од сталних и свакидашњих потреба живота човечјег и једног од његових првих занимања" (Белић 1921: 178-179). 
је ка општесловенској акцентологији. Круну Белићевих акценатских истраживања чине Акценатске студије (Београд 1914), дјело које је у своје вријеме одиграло „значительную роль в истории славянской акцентологии" (Бернштајн 1976: 63).

До Првог свјетског рата Белићеве везе с Русијом (с Руском академијом наука, Московским и Лењинградским универзитетом), биле су веома чврсте: то је период у којем су се, под окриљем руске лингвистичке школе, профилисала Белићева лингвистичка интересовања. Самуил Бернштајн неодлучно тврди како Белићево лингвистичко учење своје корене налази у учењу Ф. Фортунатова и А. Шахматова као најснажнијих представника наведене школе, али из низа факата које наводи, сасвим се оправдано може да извуче закључак како је Белићево учење, посебно у периоду до Првог свјетског рата, непосредно и снажно утемељено на схватањима Руске лингвистичке школе.?

Иза овог слиједи кратак приказ Белићевих веза с Русијом послије Другог свјетског рата. Оно што Бернштајн наводи у последњој четвртини својих успомена, од већег је значаја за Белићеву биографију него за саму природу Белићевих лингвистичких погледа. Међу овим, ипак се издвајају Белићева предавања (из историјске граматике и граматике српског књижевног језика) држана на Московском универзитету 1947. године, те курс намијењен московским лингвистима Основные проблемы общей теории языка: „Лекции сербского академика явились заметным событием в лингвистической жизни Москвы” (Бернштајн 1976: 64). Ауторов приказ Памяти академика Александра Белича завршићемо једним уопштеним запажањем: „А. Белич был прекрасным рассказчиком, обладал редким чувством юмора, был очень наблюдательным человеком. Его воспоминания и рассказы о А. А. Кочубинском, И. В. Ягиче, Ф. Ф. Фортунатове, Ф. Е. Корше, А. А. Шахматове, А. Лескине, Л. Стояновиче и многих других были всегда интересными, потому что содержали новое, неизвестное, яркое. И все это на русском языке, которым он владел безупречно" (Бернштајн 1976: 64).

7 Пишући о значају Руске лингвистичке школе, Александар Белић за Ф. Ф. Фортунатова (као једног „од својих најуваженијих учитеља”), наводи: „Његов прави и његов велики значај био је у његовој слушаоници, у његовим предавањима” (Белић 1921; 172), и даље: „Особито су од великог значаја Фортунатовљева прецизна утврђивања особина прасловенског језика, његова гласовног и морфолошког склопа, а нарочито словенског глагола. Фортунатов у томе правцу значи епоху за испитивање свих словенских језика” (Белић 1921: 173). 
Elizabeth Hill: Cећаюа на Александра Белића

У не тако обимном раду насловљеном као Сећаға на Алксандра Белићa, Elizabeth Hill (Хил 1976) настојала је да начини скицу за портрет Александра Белића. Скица је замишљена тако да се Александар Белић представи као слависта, ентузијаста који је веома рано стекао атрибут научника великога гласа, организатор научнога живота (својеврсна спона славистичких научних веза покиданих у Другом свјетском рату), као научник снажне ерудиције и оштроумних погледа, као педагог, брижан породични човјек, особа високих моралних начела.

Своје излагање Е. Хил отпочиње присјећањем како је (као студент тек основаних славистичких студија на Лондонском универзитету) далеке 1922. године први пут чула за име Александра Белића. Њен осврт на активност и дјело проф. Белића (углавном изложен као импресија) прати га надаље до Међународног састанка слависта одржаног у Београду 1955. године ${ }^{8}$ и Међународног славистичког конгреса у Москви из 1958. године. Она, дакле, обухвата у науци о језику најпродуктивнији период Белићеве дјелатности, али се по природи осврта не упушта у оцјену Белићевих језичких гледишта и оцјену његових лингвистичких домета. Ту искрсава сјећање на писмо које је Белић упутио Бодуену де Куртенеу (штампано 1913. год.), писмо које као ријетко шта друго открива шта то представља прави научни рад заснован на дијалекатској грађи и шта би морали да буду његови научни домети. Е. Хил надаље помиње рану фазу развоја славистике у Енглеској и њихове истраживаче (Де Бреј, Кенет Матјус) што су веома цијенили Белићев научно-истраживачки рад, почаст коју је Белићу указао Универзитет у Глазгову изабравши га 1951. за доктора honoris causa, његову посјету тек основаној катедри за славистику у Кембриџу итд.

Сажимајући своје сјећање на Београдски састанак слависта из 1955. године (на којем је Београд представљен као мост спајања међу слави-

8 На овом славистичком скупу као представник Велике Британије Елизабет Хил је у научноинформативној секцији поднијела реферат под насловом The Development of Slavic Studies in Britain during the last decade. Напоменимо узгред и то да се А. Белић отварајући поменути састанак, веома похвално изразио о научницима из других, несловенских средина који су задужили славистику. Међу осталим, тада је навео: „Ona [njihova slavistika] nam pokazuje, šta je osobito korisno, kako se pravac naučnih ispitivanja tih zemalja, kako se duh i talenat njihovih pretstavnika, ukoliko se oni bave slavistikom, ogledaju u njihovim delima. Setimo se samo Leskiena, Sieversa, O. Brocha, A. Meillet-a i toliko drugih koji su učinili dragocenih usluga slovenskoj nauci!" (Белић, Izveštaj: 7). 
стима различитих земаља, предратним и посљератним, а академик Белић као средишња фигура достојна највишег уважавања и највеће пажње), Елизабет Хил је своје сјећање на проф. Белића (на Александра Ивановича, како га је већ звала) у емотивном тону сажела на сљедећи начин: „Овај Нестор међу славистима, већ у својој осамдесетој години, држао нас је у напетости не само на овоме значајном састанку него и на свима осталим сусретима слависта, где је он као централна фигура тако мудро, с ауторитетом предавао [...] Александар Белић први је имао храброст отклонити ту аномалију раскинутих научних веза и саставити их поново. Почела је [у славистици] нова ера" (Хил 1976: 71).

Из ријечи Елизабет Хил, из цјелокупног њеног сјећања на најимпозантнију фигуру у српској лингвистици XX вијека, могло је заправо само да се назре колико је цијенила његово разнородно језичко дјело, колико је држала до Белићеве самосвојности у проучавању језичких факата, до његове идејне загледаности у сложени свијет међусловенских језичких веза, до Александра Белића уопште као једног од највећих слависта свога времена.

\section{ЛИТЕРАТУРА}

Белић 1921: Александар Белић, „Руска лингвистичка школа”, Јужнословенски филолог, књ. II, 169-179.

Белић 1926-1927: Александар Белић, „Мисли о прикупљању диалекатског материала", Јужнословенски филолог, VI, 1-10.

Белић 1931: Александар Белић, „Фонолошка конференција у Прагу од 18 до 21 децембра 1930 год., Јужнословенски филолог, X/1-3, 186-190.

Бернштајн 1976: Самуил Борисович Бернштейн, „Памяти академика Александра Белича", Зборник радова о Александру Белићу, Српска академија наука и уметности, Посебна издања, књ. CDXCVIII, Одељење језика и књижевности, књ. 28, Београд, 61-65.

Вајан 1976: André Vaillant, „Quelques souvenirs sur Alexandre Belić”, Зборник радова о Александру Белићу, Српска академија наука и уметности, Посебна издања, књ. CDXCVIII, Одељење језика и књижевности, књ. 28, Београд, 53-54.

Izveštaj: Izveštaj o Međunarodnom slavističkom sastanku održanom u Beogradu od 15 do 21 septembra 1955 (репринт), Александар Белић - српски лингвиста века, књ. 1 (зборник радова), Филолошки факултет, Београд (у додатку). 
Јакобсон 1976: Роман Якобсон, „Александр Белич на Пражской фонологической конференции", Зборник радова о Александру Белићу, Српска академија наука и уметности, Посебна издања, књ. CDXCVIII, Одељење језика и књижевности, књ. 28, Београд, 55-59.

Јовић 1972: Душан Јовић, „О месту Ferdinanda de Saussura, Александра Белића и Leonarda Bloomfielda у лингвистици XX века", Јужнословенски филолог, XXIX/1-2, 49-80.

Куљбакин 1921: Стјепан Куљбакин, „А. Белић”, Зборник филолочких и лингвистичких студија А. Белићу поводом 25-годичнице юегова научног рада, Академска књижара С. Б. Цвијановића, Београд, VII-XIII.

Половина 2016: Весна Половина, „Епистемолошке основе Белићеве лингвистике", Александар Белић - српски тингвиста века, књ. 1 (зборник радова), Филолошки факултет, Београд, 55-75.

Станојчић 2016: Живојин Станојчић, „Александар Белић и наш књижевни језик - граматичко мишљење Александра Белића", Александар Белић - српски тингвиста века, књ. 1 (зборник радова), Филолошки факултет, Београд, 19-41.

Стевановић 1976: Михаило Стевановић, „Живот и дело Александра Белића", Зборник радова о Александру Белићу, Српска академија наука и уметности, Посебна издања, књ. CDXCVIII, Одељење језика и књижевности, књ. 28, Београд, 3-50.

Хил 1976: Elizabeth Hill, „Сећања на Александра Белића”, Зборник радова o Александру Белићу, Српска академија наука и уметности, Посебна издања, књ. CDXCVIII, Одељење језика и књижевности, књ. 28, Београд, 67-73.

\section{Neđo Jošić}

\section{ALEKSANDAR BELIĆ IN THE MEMORIES OF FOREIGN SLAVICISTS}

\section{Summary}

On Aleksandar Belićs death, several reputable Slavicists (in the Proceedings in Honour of Aleksandar Belić, Belgrade, 1976) presented their memories of him. As in reminiscences in their own right, these memories reveal Aleksandar Belićs role in the development of Slavic scholarship in the first half of the 20th century, his pedagogical and organisational activity. Vaillant's memories (Quelques souvenirs sur Alexandre Belić) illustrate all the rigour of Belićs's scientific methodo- 
logy, profile his spirit as a researcher and clarify Belićs supervising role in their mutual cooperation. The central place in Jakobson's review (Александр Белич на Пражской фонологической конференции) is occupied by Belićs 1930 Prague paper submitted under the title "Laccent de la phrase et l'accent du mot”. Evaluating Belić as a highly gifted dialectologist, Bernstein's contribution (Памяти академика Александра Белича) also offers a trove of information on Belićs Moscow years, on particular Slavic conferences, Belićs cooperation with the Russian Academy of Sciences, on some esteemed personages from the world of Slavic scholars with whom he kept a correspondence, etc. Elizabeth Hill's contribution (Memories of Aleksandar Belić) draws a unique portrait of Aleksandar Belić: she represented him as a Slavicist who gained an early reputation as a scholar of powerful erudition and high reputation, as a very successful organiser of scientific life, as an educator and a person of high moral integrity.

The presented memories do not foreground an emotional relationship with Belić as a collaborator, teacher or friend, but Belićs capacious and complex oeuvre whose individual segments are presented from the angle of his contemporaries - in the way they comprehended and viewed them contemporaneously. 